\title{
Effect of Burning on Infiltration, Sediment, and Other Soil Properties in a Mesquite- Tobosagrass Community
}

\author{
DARRELL N. UECKERT, TERRY L. WHIGHAM, AND BRIAN M. SPEARS
}

Highlight: Burning had a minimal effect on rainfall infiltration and sediment load in runoff from a mesquite-tobosagrass community on slopes less than $1 \%$. Most soil physical properties that affect infiltration on these heavy clay soils were not altered significantly by burning. Potential soil loss in runoff can be minimized by burning under relatively moist conditions. Larger soil aggregates were broken down by burning and had not returned to equilibrium on 5-year-old burns. Trends in levels of soil organic carbon, salinity, sodium, and potassium following burning varied with degree of soil cracking, which is a function of soil moisture.

Fire has proven useful in mesquite (Prosopis glandulosa var. glandulosa)-tobosagrass (Hilaria mutica) communities for removing dead honey mesquite, removing excessive accumulations of tobosagrass litter, increasing yield and utilization of tobosagrass, and for controlling honey mesquite, annual broomweeds (Xanthocephalum dracunculoides), and three species of cactus (Opuntia spp.) (Wright 1974).

Sharrow and Wright (1977a) reported that burning in March increased soil temperatures throughout spring and summer and increased the rate of soil nitrogen mineralization in tobosagrass communities. With adequate soil moisture, higher soil temperatures stimulated growth of tobosagrass with concomitant reductions in soil moisture and nitrates as compared to unburned controls. Neuenschwander et al. (1974) reported that soil

At the time of the research, the authors were associate professor and graduate research assistants, Department of Range and Wildlife Management, Texas Tech University, Lubbock. Darrell Ueckert's present address is Texas A\&M University Agricultural Research and Extension Center, San Angelo, Texas 76901; Terry Whigham's, U.S.D.A., Soil Conservation Service, Uvalde. Texas 78801 ; and Brian Spears' Dept. of Entomology, University of Idaho, Moscow 83843.

This report is a contribution of Texas Tech University, College of Agricultural Sciences, Publication Number T-9-179. organic carbon levels and bacterial counts increased following March burning and returned to normal within 6 years following burning in tobosagrass communities. Sharrow and Wright (1977b) concluded that burning too frequently (more often than once each 5 to 8 years) may deplete soil nitrogen reserves and reduce future plant growth.

Burning has reduced infiltration rates in soils of Missouri Ozark forests (Arend 1941), of chaparral communities of northern California (Sampson 1944), of Flint Hills tall grass prairie of Kansas (Hanks and Anderson 1957), and of Douglas fir (Pseudotsuga menziesii) forests of British Columbia (Beaton 1959). However, Scott (1956) reported increased infiltration on upland soils in California following fire as did Tarrant (1956) for a ponderosa pine (Pinus ponderosa) forest in eastern Washington. Veihmeyer and Johnston (1944) detected no impairment of infiltration rates on burned chamise (Adenostoma sp.) communities in northern California.

Burning has been reported to increase runoff and soil loss in woodland-chaparral-grass communities of the Sierra Nevada foothills (Rowe 1941), in the White Mountains of Arizona (Cooper 1961), in oak (Quercus sp.)-mountain mahogany (Cercocarpus sp.) chaparral (Pase and Lindenmuth 1971), and in chaparral communities of northern California (Sampson 1944). However, Veihmeyer (1951) reported that burning did not accelerate runoff or erosion on several watersheds with a variety of cover types, soils, topography and precipitation in northern California, as did Biswell and Schultz (1957) for ponderosa pine forests in northern California.

Mesquite-tobosagrass rangeland is an important grazing resource in Texas, New Mexico, Arizona, and northern Mexico (Neuenschwander et al. 1975). All effects of burning should be thoroughly evaluated for proper planning of burning schedules. 
This study was conducted to determine the effects of fire in a mesquite-tobosagrass community upon selected physical and chemical properties of the soil by comparing these properties on burns of different ages and on unburned plots.

\section{Methods and Materials}

\section{Study Area}

The study was conducted on the Spade Ranch, $22.5 \mathrm{~km}$ (14 miles) south of Colorado City in Mitchell County, Texas. The average annual precipitation is $50.2 \mathrm{~cm}$ (19.8 inches), about $78 \%$ of which falls between April and October. The winters are relatively mild with brief cold periods. The average daily maximum temperature in July and August is $36^{\circ} \mathrm{C}\left(97^{\circ} \mathrm{F}\right)$. The average annual evaporation is about 254 $\mathrm{cm}$ (100 inches) with approximately $66 \%$ occurring during the May to October period (Stoner et al. 1969).

The study area is occupied by the Stamford soil series which is mapped with the Dalby series in an undifferentiated unit. The Stamford series is classified as fine, montmorillonitic, thermic Typic Chromusterts while the Dalby series is classified as fine, mixed, thermic Typic Chromusterts. The Stamford series consists of nearly level areas ( 0 to $1 \%$ slope) of deep and well-drained calcareous clays (Stoner et al. 1969). The plant community on the study area has been described by Neuenschwander (1976).

Study plots were established within a 1-mile radius on large plots burned with headfires in March of 1975, 1974, 1972, or 1969, and on an unburned area. Plots were located on relatively homogenous Stamford soils with gentle slopes $(0.6$ to $0.9 \%)$. All plots were within a single pasture. Burning treatments were not replicated. Field data were collected during the late spring of 1974 and 1975.

\section{Infiltration, Erosion and Selected Soil Physical Properties}

A modified Purdue sprinkling infiltrometer (Bertrand and Parr 1961) was used to simulate rainfall at a rate of $11.4 \mathrm{~cm} / \mathrm{hr}$ over a 40-minute period to randomly located Rocky Mountain infiltrometer microplots $\left(0.236 \mathrm{~m}^{2}\right)$ (Dortignac 1951). Infiltration tests were replicated nine times on each age ot burn and each unburned plot. Each microplot was prewetted with approximately $3.4 \mathrm{~cm}(1.3$ inches) of water 24 hours prior to treatment to remove major differences in antecedent soil moisture and to eliminate soil cracking. The amounts of rainfall applied to each microplot and subsequent runoff were measured at 5-minute intervals during the 40 -minute period. Infiltration was calculated as the difference between rainfall and runoff. The runoff from each microplot was collected and upon termination of the simulated rainfall application, was thoroughly agitated and subsampled in 0.95 -liter quantities. These subsamples were allowed to settle for 2 weeks before the supernatant water was siphoned off. The sediment was oven-dried at $105^{\circ} \mathrm{C}$ for 24 hours, weighed and used as an index of erosion or sediment load. Antecedent soil moisture from each microplot was determined by the gravimeteric method (Gardner 1965 ) from three, $2.54-\mathrm{cm}$ diam by $15-\mathrm{cm}$ soil cores taken just outside the boundaries of each microplot.

Infiltration was also evaluated with a double-ring infiltrometer (Marshall and Stirk 1950) on each burned and untreated plot in early July of 1974 and 1975 . Each randomly located microplot was prewetted with approximately $3.4 \mathrm{~cm}$ (1.3 inches) of water 24 hours prior to testing. Measurements were taken at 5-minute intervals during a 1-hour period. Double-ring infiltration tests were replicated nine times upon cach treatment. We utilized this "ponding" approach, in addition to the "simulated rainfall" techrique because tobosagrass communities commonly occur in depressions or concave sites which receive runoff from hillsides or convex sites. Water commonly accumulates in these concave sites following heavy rainfall.

Grasses, forbs, and litter were collected from each microplot after the infiltration tests to determine the effects of these factors on infiltration rates and sediment loads. The grasses and forbs were clipped as close to the soil surface as possible 1 day after infiltration tests and oven-dried at $63^{\circ} \mathrm{C}$ for 72 hours. Litter was collected with a modified Devac ${ }^{\circledR}$ insect vacuum and dried for 72 hours at $63^{\circ} \mathrm{C}$. Oven-dried subsamples of litter were ground in a Wiley ${ }^{\circledR}$ mill, then ashed in a muffle furnace at $600^{\circ} \mathrm{C}$ for 8 hours for conversion of oven-dry weights to ash-free weights.

Five vertical, undisturbed soil cores, $5.4 \mathrm{~cm}$ in diam by $5.9 \mathrm{~cm}$ in length, were taken from the upper $5.9 \mathrm{~cm}$ of the soil profile in each microplot after removal of herbage and litter. From these cores, bulk densities were determined (Blake 1965), total porosity, capillary porosity and noncapillary porosity were measured using the tensiontable method (Vomocil 1965), and hydraulic conductivity was determined by the constant-head method (Klute 1965).

The textural analysis was determined for the All horizon from each microplot cluster using the hydrometer method (Day 1965). Soil aggregate classes of $>3 \mathrm{~mm}, 3$ to $2 \mathrm{~mm}, 2$ to $1 \mathrm{~mm}, 1$ to $0.5 \mathrm{~mm}, 0.5$ to $0.25 \mathrm{~mm}$ and $<0.25 \mathrm{~mm}$ were determined on duplicate bulk soil samples taken from the 0 to $1-\mathrm{cm}$ increment of each microplot using the method for water stable aggregates (Kemper and Chepil 1965). Bulk soil samples for aggregate analysis were collected prior to the 1975 burn in addition to the post-burn sampling.

\section{Soil Chemical Properties}

Bulk soil samples taken from the 0 to 1,1 to 2 , and 2 to $4-\mathrm{cm}$ increments from each microplot were used for determination of soil organic carbon (Allison 1965). Soil samples from the 0 to $2.54-\mathrm{cm}$ increment in each microplot were used in preparing a saturated paste extract (Richards 1954) from which sodium and potassium contents (Fields et al. 1951) and soil salinity (Richards 1954) were determined. Soil reaction (Fields and Parrot 1966) was determined from the saturated paste using a Beckman ${ }^{\circledR} \mathrm{pH}$ meter. Bulk soil samples for chemical analyses were taken prior to the 1975 burn in addition to the post-burn sampling.

\section{Statistical Analyses}

Data for all soil properties were analyzed with analyses of variance to determine differences among treatments. Variation among subsamples within treatments was utilized as the estimate of error. Duncan's multiple range test was used where appropriate to separate means (Snedecor and Cochran 1967). Linear stepwise multiple regression was used to determine which soil and site factors accounted for variations in infiltration rates and sediment loads within each treatment.

\section{Results and Discussion}

\section{Infiltration}

Initially, differences were observed in simulated rainfall infiltration rates among the burns of different ages. However, these differences seemed to be related to site differences rather than to effects of fire. Analysis of variance revealed that bulk density, noncapillary porosity, capillary porosity, total porosity, antecedent soil moisture, hydraulic conductivity, and fractions of sand, silt, and clay were significantly different among the sites. Analyses of covariance using bulk density, noncapillary porosity, capillary porosity, silt, sand, and antecendent soil moisture as covariables isolated no significant differences in total (entire 40-minute period) infiltration between treatments as determined with the modified Purdue sprinkling infiltrometer (Table 1). Similarly, there were no differences in infiltration rates among treatments within any of the 5-minute intervals during the 40-minute period of simulated rainfall, including the terminal infiltration rate. However, the double ring infiltrometer revealed significant differences in infiltration rates among treatments. Infiltration was lowest on recently burned areas and increased with time following burning (Table 1). Infiltration rates on burned areas approached that of unburned areas after 2 to 3 years (Table 1). The double-ring infiltrometer tends to exaggerate differences in infiltration rates, because of the constant hydraulic head effect.

Linear stepwise multiple regression was performed for each different age burn and unburned plot to determine the relationship between soil and site characteristics with infiltration rates. Regression equations showed that the most important factors affecting infiltration rates on these heavy clay soils were those dealing with the physical soil characteristics. Bulk density and noncapillary porosity were the most important of these characteristics. The larger aggregate classes were 
Table 1. Adjusted (by covariance) means of Purdue sprinkling infiltrometer infiltration rates (cm/40 min), double-ring infiltrometer infiltration rates $(\mathrm{mm} / \mathrm{hr}$ ) sediment production (g/liter), mean standing vegetation (kg/ha) and ash-free surface litter accumulation (kg/ha) on different age burns and unburned plots in a mesquite-tobosagrass community in Mitchell County, Texas.

\begin{tabular}{|c|c|c|c|c|c|}
\hline \multirow[b]{2}{*}{ Treatment } & \multicolumn{5}{|c|}{ Variables } \\
\hline & $\begin{array}{l}\text { Infiltration } \\
\text { (Purdue) } \\
\text { (cm/40 min) }\end{array}$ & $\begin{array}{l}\text { Infiltration } \\
\text { (Rings) } \\
\text { (mm/hr) }\end{array}$ & $\begin{array}{l}\text { Sediment } \\
\text { (g/liter) }\end{array}$ & $\begin{array}{l}\text { Standing vegetation } \\
\mathbf{k}(\mathbf{k g} / \mathrm{ha})\end{array}$ & $\begin{array}{l}\text { Litter } \\
\text { (ash-free) } \\
\text { (kg/ha) }\end{array}$ \\
\hline None (1975) & $5.3 \mathrm{a}^{1}$ & $130 \mathrm{de}$ & $0.06 \mathrm{a}$ & $4958 \mathrm{e}$ & $3517 \mathrm{~g}$ \\
\hline None (1974) & $6.1 \mathrm{a}$ & $98 \mathrm{~cd}$ & $0.15 \mathrm{a}$ & $4110 \mathrm{~cd}$ & $3008 \mathrm{f}$ \\
\hline 5-year-old bum & $5.3 \mathrm{a}$ & $150 \mathrm{e}$ & $0.11 \mathrm{a}$ & $4195 \mathrm{~cd}$ & $1780 \mathrm{e}$ \\
\hline 3-year-old burn & $3.6 \mathrm{a}$ & $91 \mathrm{bcd}$ & $0.27 \mathrm{ab}$ & $3644 c$ & 932 bc \\
\hline 2-year-old burn & $3.1 \mathrm{a}$ & $83 \mathrm{abc}$ & $0.23 \mathrm{ab}$ & $3729 c$ & $1271 \mathrm{c}$ \\
\hline 1-year-old burn & $5.1 \mathrm{a}$ & $64 a b c$ & $0.43 b$ & 4492 de & $1398 \mathrm{de}$ \\
\hline $\begin{array}{l}\text { Recent burn } \\
\text { (1974) }\end{array}$ & $6.4 \mathrm{a}$ & $46 a$ & $1.28 \mathrm{c}$ & 381 a & $424 a$ \\
\hline $\begin{array}{l}\text { Recent burn } \\
\text { (1975) }\end{array}$ & $2.8 \mathrm{a}$ & $79 \mathrm{abc}$ & $0.28 \mathrm{ab}$ & $1144 \mathrm{~b}$ & $636 a b$ \\
\hline
\end{tabular}

${ }^{1}$ Means within a column followed by the same letter are not significantly different at the $90 \%$ level of significance.

next in importance. Standing vegetation and organic carbon, those factors affected directly by fire, were of lesser importance in affecting infiltration rates.

\section{Standing Vegetation and Litter}

Dry weights of vegetation and litter were reduced $91.2 \%$ and $85.7 \%$, respectively, on the 1974 burn, and $77 \%$ and $82.2 \%$, respectively, on the 1975 burn compared to dry weights on the respective unburned plots (Table 1). The biomass of standing vegetation on the 1-year-old burn exceeded that on the 2- and 3-year-old

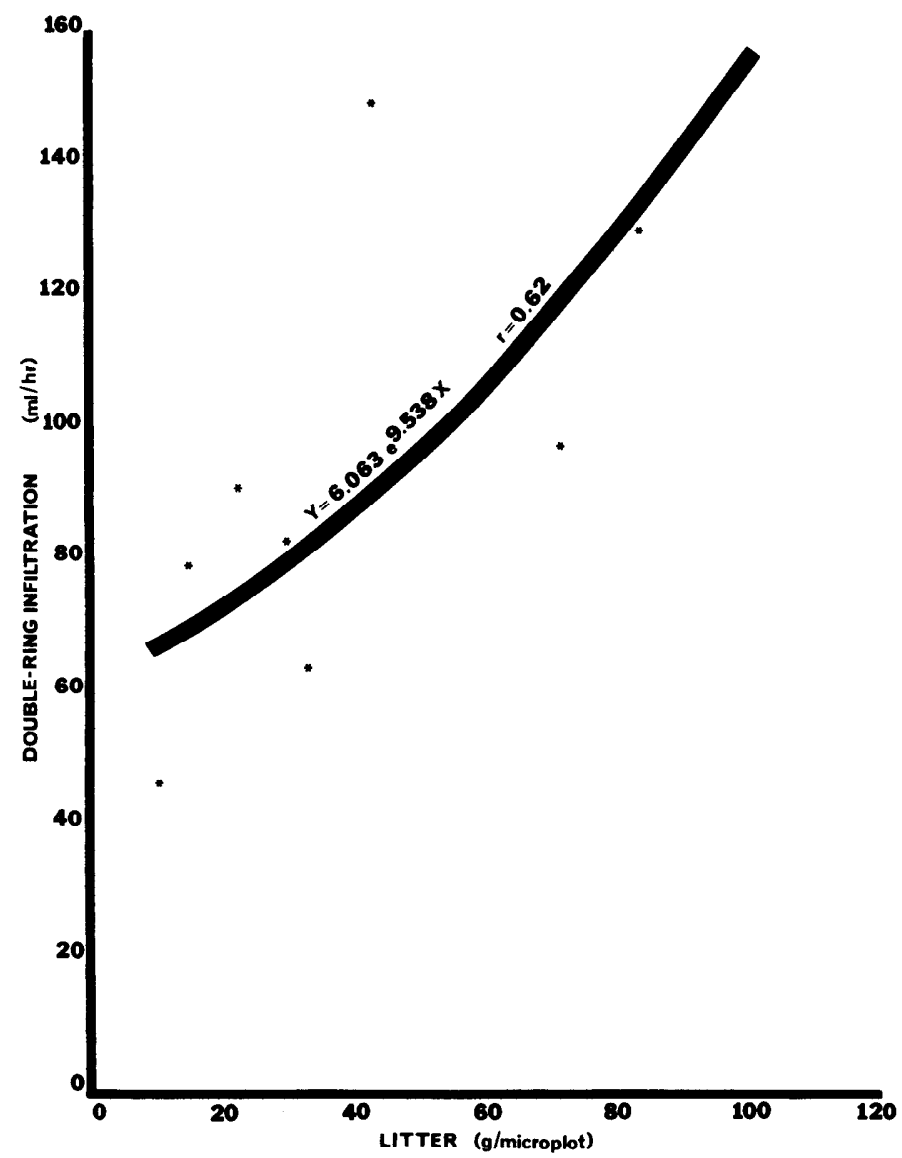

Fig. 1. Relationship between infiltration rates $(\mathrm{mm} / \mathrm{hr})($ determined by a double-ring infiltrometer) and surface litter accumulation (g/microplot) on burns of different ages and on unburned plots in a mesquitetobosagrass community in Mitchell County, Texas. burns. However, it was composed largely of annual broomweed, due to relatively abundant fall (1974) and winter (1975) precipitation. The biomass of standing vegetation on the 5-year-old burn approached that on the unburned plots. Litter on the 1-year-old burn exceeded that on recent burns; however, litter accumulation on the 5-year-old burn was only $50 \%$ to $60 \%$ of that on the unburned plots (Table 1). Infiltration rates (double-ring method) increased exponentially as surface litter accumulation increased (Fig. 1).

\section{Sediment Load in Runoff}

Sediment load in runoff increased significantly following fire in 1974 , but not in 1975 (Table 1). Sediment load decreased rapidly the first year following the 1974 burn and continued to decrease as evidenced by the trend on 2-,3-, and 5-year-old burns. However, sediment loads from the 1975 burn and the 2- and 3-year-old burns were not significantly higher than the 5-year-old burn or that from unburned plots. The lack of protective litter seemed to account for most of the increased sediment load in the runoff immediately following fire. Sediment load in runoff increased exponentially as surface litter accumulation decreased (Fig. 2).

Sediment loads from recent burns (3-month-old) varied significantly between the 1974 and 1975 sampling dates. The sediment load from the 1974 burn, which occurred during relatively dry conditions $(7.1$ $\mathrm{cm}$ precipitation during 6-month period prior to burn), was 8.5 times greater than that of the unburned plot. The sediment load from the 1975 burn, which occurred under relatively moist conditions $(20.2 \mathrm{~cm}$ precipitation during 6-month period prior to burn), was not significantly different from sediment load from the unburned area (Table 1). Thus, burning during relatively wet seasons may reduce the amount of

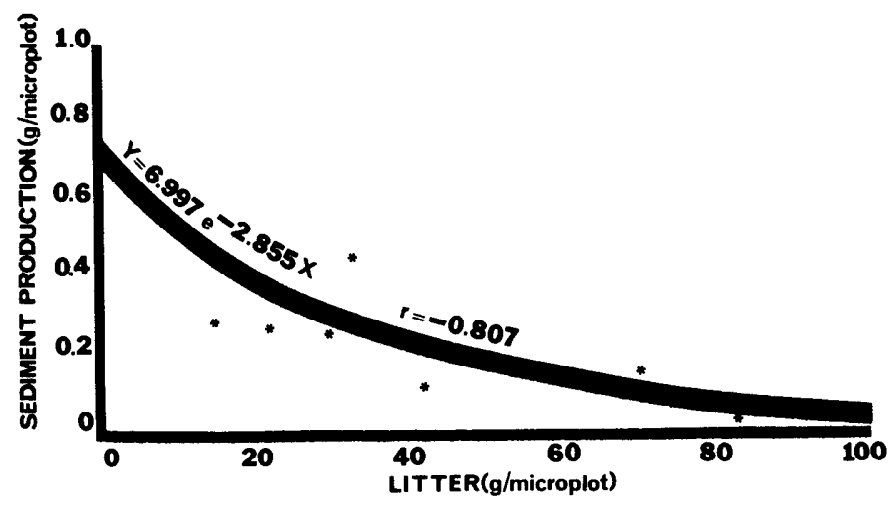

Fig. 2. Relationship between sediment production ( $\mathrm{g} /$ microplot) and surface litter accumulation ( $\mathrm{g} /$ microplot) on burns of different ages and on unburned plots in a mesquite-tobosagrass community in Mitchell County. Texas. 
Table 2. Mean percentages of soil aggregates in six size classes in the surface $\mathrm{cm}$ on different age burns and unburned plots in a mesquite-tobosa community in Mitchell County, Texas.

\begin{tabular}{|c|c|c|c|c|c|c|}
\hline \multirow[b]{2}{*}{ Treatment } & \multicolumn{5}{|c|}{ Aggregate size classes } & \multirow[b]{2}{*}{$<0.25 \mathrm{~mm}$} \\
\hline & $>3 \mathrm{~mm}$ & $3 \mathrm{~mm}-2 \mathrm{~mm}$ & $2 \mathrm{~mm}-1 \mathrm{~mm}$ & $1 \mathrm{~mm}-0.5 \mathrm{~mm}$ & $0.5 \mathrm{~mm}-0.25 \mathrm{~mm}$ & \\
\hline None (1975) & $45.3 \mathrm{~d}^{1}$ & $7.2 \mathrm{bcd}$ & $7.2 \mathrm{abc}$ & $5.4 \mathrm{ab}$ & $3.9 \mathrm{a}$ & $31.1 \mathrm{abc}$ \\
\hline None (1974) & $43.0 \mathrm{~d}$ & $8.3 \mathrm{~d}$ & $9.7 \mathrm{~d}$ & $7.8 \mathrm{bcd}$ & $4.4 \mathrm{ab}$ & $26.6 \mathrm{ab}$ \\
\hline 5-year-old burn & $26.2 \mathrm{ab}$ & $5.3 \mathrm{a}$ & $5.7 \mathrm{a}$ & $6.5 \mathrm{abcd}$ & $7.9 \mathrm{~cd}$ & $48.5 \mathrm{~d}$ \\
\hline 3-year-old burn & $22.7 \mathrm{a}$ & $6.7 \mathrm{bc}$ & $6.2 \mathrm{ab}$ & $4.9 \mathrm{a}$ & $3.9 \mathrm{a}$ & $56.1 \mathrm{e}$ \\
\hline 2-year-old burn & $31.6 \mathrm{bc}$ & $6.1 \mathrm{ab}$ & $5.6 \mathrm{a}$ & $5.5 \mathrm{abc}$ & $3.8 \mathrm{a}$ & $46.8 \mathrm{~d}$ \\
\hline 1-year-old burn & $33.7 \mathrm{c}$ & $6.7 \mathrm{bc}$ & $8.4 \mathrm{~cd}$ & 7.9 bcd & $6.1 \mathrm{~b}$ & $37.4 \mathrm{c}$ \\
\hline \multicolumn{7}{|l|}{ Recent burn } \\
\hline (1974) & $33.8 \mathrm{c}$ & $7.0 \mathrm{bcd}$ & 8.8 bcd & $8.3 \mathrm{~cd}$ & $9.4 \mathrm{~d}$ & $32.8 \mathrm{bc}$ \\
\hline \multicolumn{7}{|l|}{ Recent burn } \\
\hline$(1975)$ & $33.7 \mathrm{c}$ & $8.2 \mathrm{~d}$ & 7.9 abcd & $8.4 \mathrm{~d}$ & $5.8 \mathrm{abc}$ & $36.0 \mathrm{c}$ \\
\hline Preburn (1975) & $49.1 \mathrm{~d}$ & $8.0 \mathrm{~cd}$ & $7.9 \mathrm{abcd}$ & 6.0 abcd & $4.2 \mathrm{ab}$ & $24.8 \mathrm{a}$ \\
\hline
\end{tabular}

${ }^{1}$ Mcans within a column followed by the same letter are not significantly different at the $95 \%$ level of significance.

potential sediment loss. Exposure of the 1974 burn to the hot, dry spring and summer caused the soil to crack, be less compact, and generally be unprotected by standing vegetation and litter, which subjected it to more sediment loss.

Linear stepwise multiple regression indicated that standing vegetation alone accounted for over half of the variation $(P>0.05)$ in sediment load on burned and unburned sites. Standing vegetation, the site factor radically affected by fire, was responsible for preventing erosion or sediment load in runoff. Soil bulky density and larger aggregate size classes were of secondary importance on both sites.

\section{Soil Aggregates}

Several size classes of soil aggregates were significantly altered by fire (Table 2). The $>3-\mathrm{mm}$ size class was reduced $15.4 \%$ by the 1975 burn compared to the preburn condition. The $>3-\mathrm{mm}$ size class had not returned to normal levels on 5-year-old burns. The percentage of aggregates in the 3 to $2-\mathrm{mm}$ size class decreased through the fifth year after burning, as evidenced by the trend recorded on burns of different ages.

The 2 to $1-\mathrm{mm}$ size class was not affected by fire through the first year following burning. However, decreases were evident on 2-, 3-, and 5-year-old burns. The 1 to $0.5-\mathrm{mm}$ size class increased somewhat initially after fire, but decreased on 2- and 3-year-old burns with an upward trend toward stabilization occurring on the 5-year-old burn. A similar trend was evident in the 0.5 to $0.25-\mathrm{mm}$ size class.

The $<0.25-\mathrm{mm}$ aggregates increased considerably on the 2-year-old burn. This trend reversed on the 5-year-old burn, possibly due to the reaggregation of these particles into larger aggregates. This aggregate size class possibly increased upon breakdown of larger aggregates.
Obviously, litter and standing vegetation protect the aggregates at the soil surface and prevent their destruction by raindrop splash and exposure to other climatic influences. This is supported by the strong positive correlation between litter and the $>3-\mathrm{mm}$ aggregate size class $(r=0.71, P>0.05)$. The percentage of $>3-\mathrm{mm}$ aggregates increased as litter increased (Fig. 3).

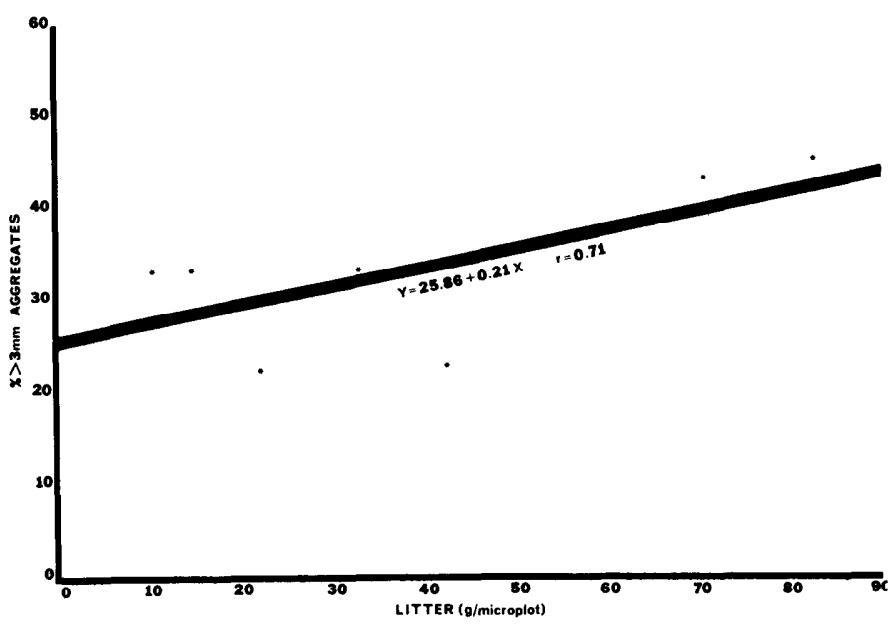

Fig. 3. Relationship between mean percentage of $>3-\mathrm{mm}$ soil aggregates and surface litter accumulation (g/microplot) on burns of different ages and on unburned plots in a mesquite-tobosagrass community in Mitchell County. Texas.

Table 3. Mean levels of organic carbon (\%), soil reaction (pH), salinity (mmhos/cm), sodium (meq/100g), and potassium (meq/100g) of different age burns and unburned plots in a mesquite-tobosa community in Mitchell County, Texas.

\begin{tabular}{|c|c|c|c|c|c|c|c|}
\hline \multirow[b]{2}{*}{ Treatments } & \multicolumn{3}{|c|}{ Organic carbon (\%) } & \multirow{2}{*}{$\begin{array}{r}\text { Soil reaction }^{3} \\
(\mathrm{pH})\end{array}$} & \multirow{2}{*}{$\begin{array}{l}\text { Salinity }{ }^{3} \\
\text { (mmhos/cm) }\end{array}$} & \multirow{2}{*}{$\begin{array}{l}\text { Sodium }^{3} \\
\text { (meq/100g) }\end{array}$} & \multirow{2}{*}{$\begin{array}{l}\text { Potassium }^{3} \\
\quad(\mathrm{meq} / 100 \mathrm{~g})\end{array}$} \\
\hline & $0-1 \mathrm{~cm}$ & $1-2 \mathrm{~cm}$ & $2-4 \mathrm{~cm}$ & & & & \\
\hline None (1975) & $2.69 c^{1}$ & $1.81 b^{1}$ & $1.56 b c^{1}$ & $7.19 a b c^{2}$ & $1.75 \mathrm{fg}^{2}$ & $0.27 \mathrm{~d}^{2}$ & $0.08 \mathrm{cde}^{2}$ \\
\hline None (1974) & $2.62 \mathrm{c}$ & $2.03 \mathrm{~cd}$ & $1.36 \mathrm{ab}$ & $7.57 \mathrm{def}$ & 1.57 cdefg & $0.08 \mathrm{a}$ & $0.06 \mathrm{ab}$ \\
\hline 5-year-old burn & $2.58 \mathrm{c}$ & $2.26 \mathrm{def}$ & $1.62 \mathrm{c}$ & 7.45 bcde & $1.29 \mathrm{abcdef}$ & $0.08 \mathrm{a}$ & $0.05 \mathrm{a}$ \\
\hline 3-year-old burn & $1.74 \mathrm{a}$ & $1.42 \mathrm{a}$ & $1.37 \mathrm{ab}$ & $7.84 \mathrm{f}$ & $1.71 \mathrm{defg}$ & $0.19 \mathrm{bc}$ & $0.06 \mathrm{ab}$ \\
\hline 2-year-old burn & $2.08 \mathrm{ab}$ & $2.07 \mathrm{cde}$ & $1.55 \mathrm{bc}$ & $7.63 \mathrm{ef}$ & $1.05 \mathrm{a}$ & $0.02 \mathrm{a}$ & $0.05 \mathrm{ab}$ \\
\hline 1-year-old burn & $3.23 \mathrm{~d}$ & $2.41 \mathrm{ef}$ & $1.93 \mathrm{~d}$ & $7.10 \mathrm{ab}$ & $1.72 \mathrm{efg}$ & $0.23 \mathrm{bcd}$ & $0.09 \mathrm{e}$ \\
\hline \multicolumn{8}{|l|}{ Recent burn } \\
\hline (1974) & $3.39 \mathrm{~d}$ & $2.57 \mathrm{f}$ & $1.89 \mathrm{~d}$ & $7.05 \mathrm{a}$ & $1.59 \mathrm{cdefg}$ & $0.04 \mathrm{a}$ & 0.09 de \\
\hline \multicolumn{8}{|l|}{ Recent burn } \\
\hline (1975) & $2.73 \mathrm{c}$ & $1.31 \mathrm{a}$ & $1.24 \mathrm{a}$ & $7.53 \mathrm{cdef}$ & $2.01 \mathrm{~g}$ & $0.23 \mathrm{~cd}$ & 0.07 bcde \\
\hline Preburn (1975) & $2.26 \mathrm{bc}$ & $1.52 \mathrm{ab}$ & $1.22 \mathrm{a}$ & $7.21 \mathrm{abc}$ & $0.95 \mathrm{a}$ & $0.02 \mathrm{a}$ & $0.05 \mathrm{a}$ \\
\hline
\end{tabular}

\footnotetext{
'Means within this column followed by the same letter are not significantly different at the $95 \%$ level of significance.

: Means within this column followed by the same letter are not significantly different at the $90 \%$ level of significance.

"Within upper $2.54 \mathrm{~cm}$ ( 1 in.) of soil
} 


\section{Organic Carbon}

Soil organic carbon increased significantly in the upper $4 \mathrm{~cm}$ following the 1974 burn but was not affected by the 1975 burn (Table 3 ). A possible explanation for a different trend in 1975, compared to 1974, may be the differences in precipitation. In 1974, from October until the time of the burn in March, $7.1 \mathrm{~cm}$ (2.8 inches) of precipitation occurred. There was $20.2 \mathrm{~cm}$ (8.0 inches) of precipitation within that same interval in 1975. Increased precipitation in 1975 resulted in abundant soil moisture, thus a farily smooth soil surface without surface cracking. Less cracking and mulching of the Stamford clay during and after the 1975 burn apparently did not promote incorporation of unburned charcoal, ash, or residual litter into the soil surface layers. Organic carbon increased rapidly the year of the burn as the ash and unburned charcoal were incorporated into the soil immediately below the surface (as in the case of the 1974 burn). Thereafter, there was a slight decline in soil organic carbon the first year with a more rapid reduction in 2- and 3-year-old burns and a return to near equilibrium on the 5-year-old burn. A possible explanation for this trend may be the increased temperatures of the blackened soil surface following fire, which stimulates decomposer populations. These decomposers consume the organic carbon for their energy source and reach their population peaks by the end of the first year (Neuenschwander et al. 1974). Soil organic carbon is rapidly decomposed during the second and third years following burning. By 5 years after burning, 50 to $60 \%$ of the normal litter accumulation had been redeposited (Table 1) and soil organic carbon levels had returned to equilibrium. Neuenschwander et al. (1974) indicated that $2.65 \%$ soil organic carbon was the equilibrium state in tobosagrass communities, which is firmly substantiated by our data for the 0 to $1-\mathrm{cm}$ increment.

\section{Soil Reaction}

The soil $\mathrm{pH}$ prior to the 1975 burn was 7.21 , compared to 7.53 after burning (Table 3). This was not a significant change, and all differences in soil reaction seemed to be related to site differences rather than to fire. No trends in $\mathrm{pH}$ change with time lapse following burning were evident. Increases in soil $\mathrm{pH}$ following burning have been reported by Austin and Baisinger (1955), Marshall and Averill (1928), Bamette and Hester (1930), Heyward and Barnette (1934), Isaac and Hopkins (1937), and Nye and Greeland (1964).

\section{Salinity}

Salinity within the surface $2.54 \mathrm{~cm}$ ( 1 inch) of soil was increased by the fire in March, 1975. Salinity before the fire was $0.95 \mathrm{mmhos} / \mathrm{cm}$, compared to $2.01 \mathrm{mmhos} / \mathrm{cm}$ after the fire and to the $1.75 \mathrm{mmhos} / \mathrm{cm}$ in the unburned plots. However, fire did not increase soil salinity following the 1974 burn compared to that on unburned plots. Since there was no surface cracking in 1975, the ash may have been confined to the surface, thus concentrating the salts. Under the drier conditions of 1974 , the soil cracking and mulching would tend to diffuse the ash throughout the profile, thus giving lower salinity values for the surface $2.54 \mathrm{~cm}$. No other temporal trends in soil salinity were evident. Salinity values appeared to vary with site variations among plots.

\section{Sodium and Potassium}

The sodium content of the soil after the 1975 burn was 0.23 $\mathrm{meq} / 100 \mathrm{~g}$, compared to $0.02 \mathrm{meq} / 100 \mathrm{~g}$ before the burn (Table 3). However, the soil sodium level in the 1974 unburned plot was not significantly different from that of the burn. This discrepancy in sodium content in the upper $2.54 \mathrm{~cm}$ following burning in a wet year compared to a dry year is probably also related to surface cracking. No other trends were detected with the lapse of time after burning.

Potassium contents were significantly different among soils from the different age burns and unburned areas (Table 3), indicating considerable site variation. Potassium levels in the upper $2.54 \mathrm{~cm}$ of soil of the 1974 and 1975 burns significantly increased compared to the unburned plot and the 1975 preburn sampling. The potassium content remained the same for 1 ycar and then declined the second year, probably due to a combination of plant use and leaching. Soil sodium, potassium, calcium, magnesium, and sulfur have been reported to increase following burning in several studies (Heyward and Barnette 1934; Austin and Baisinger 1955; Vlamis and Gowans 1961; Nye and Greenland 1964; Smith 1970).

\section{Conclusions}

Burning may slightly reduce infiltration rates of Stamford clay soils in tobosagrass communities. The effect does not appear to be significant under normal rainfall conditions, but may be on concave sites where runoff accumulates. Soil bulk density, noncapillary porosity, and large size classes of soil aggregates were the most important site characteristics affecting rainfall infiltration; and of these factors, only the large aggregates seemed to be significantly affected by March burning of tobosagrass. Standing vegetation played a role of lesser importance in affecting infiltration. Surface litter accumulation may be an important factor affecting infiltration in swales or concave sites, where water accumulates after rains.

Sediment loss in overland flow increased following burning of tobosagrass on slopes of less than $1 \%$, but total soil loss was not significant and within 2 to 3 years the sediment load stabilized. Potential sediment loss may be minimized by burning when soils are relatively moist. Standing vegetation was the major factor regulating sediment load in runoff. Sediment load in runoff increased exponentially as surface litter accumulation decreased.

Larger sizes of soil aggregates break down following burning in tobosagrass communities, resulting in an increase in small aggregates. Recovery of aggregates to preburn levels had not occurred on a 5-year-old burn. The reduction of surface litter by fire was highly associated with the breakdown of large soil aggregates.

The degree of cracking of this heavy clay determined the trend in levels of soil organic carbon, salinity, sodium, and potassium. Ashes and unburned debris were incorporated and soil organic carbon levels increased when burns were conducted when the soil was dry and cracked; whereas when soils were moist, soil organic levels were not significantly changed. Burning in relatively wet years may increase salinity, sodium, and potassium in the upper $2.54 \mathrm{~cm}$ ( $1 \mathrm{inch}$ ) of soil; whereas in drier years, these substances are dispersed in the soil profile due to soil cracking. Soil $\mathrm{pH}$ was not significantly affected by burning.

In general, fire as a management tool in tobosagrass communities in West Texas does not adversely affect soil physical or chemical properties. Most effects are of a minimal nature and stabilization occurs within 3 to 5 years after the fire. Tobosagrass communities should be burned when soils are relatively moist, not only to assure better plant response, but also to minimize potential soil loss in runoff.

\section{Literature Cited}

Allison, L.E. 1965. Organic carbon p. 1367-78. In: Methods of Soil Analysis. C.A. Black (Ed.) No. 9 Monogr. Ser. Part II. Amer. Soc. Agron. Arend, J.L. 1941. Infiltration rates of forest soils in the Missouri Ozarks as affected by woods burning and litter removal. J. Forest. 39:726-728.

Austin, R.C., and D.H. Baisinger. 1955. Some effects of burning on forest soils of western Oregon and Washington. J. Forest. 53:275-280.

Barnette, R.M., and J.B. Hester. 1930. Effect on burning upon the accumulation of organic matter in forest soils. Soil Sci. 29:281-284.

Beaton, J.D. 1959. The influence of burning on the soil in the timber range area of Lac Le Jeune, British Columbia. I. Physical properties. Can. J. Soil Sci. $39: 1-5$.

Bertrand, A.R., and J.F. Parr. 1961. Design and operation of the Purdue sprinkling infiltrometer. Purdue Univ. Agr. Exp. Sta. Bull. No. 723. 16 p. 
Biswell, H.M., and A.M. Schultz. 1957. Surface runoff and erosion as related to prescribed burning. J. Forest. 55:372-374.

Blake, G.R. 1965. Bulk density, p. 374-90. In: Methods of Soil Analysis. C.A. Black (Ed.) No. 9 Monogr. Ser. Part I. Amer. Soc. Agron.

Cooper, C.F. 1961. Controlled burning and watershed condition in the White Mountains of Arizona. J. Forest. 59:438-442.

Day, P.R. 1965. Particle fractionation and particle size analysis. p. 454-567. In: Methods of Soil Analysis. C.A. Black (Ed.) No. 9 Monogr. Ser. Part I. Amer. Soc. Agron.

Dortignac, E.J. 1951. Design and operation of the Rocky Mountain infiltrometer. U.S. Forest Service, Rocky Mountain Forest and Range Exp. Sta. Paper 5. $68 \mathrm{p}$.

Fieldes, M., P.J.T. King, J.P. Richardson, and L.D. Swindale. 1951. Estimation of exchangeable cations in soils with the Beckman flame spectrophotometer. Soil Sci. 72:219-323.

Fieldes, M., and K.W. Parrott. 1966. The nature of allophane in soils. III. Rapid field and laboratory test for allophane. New Zealand J. Sci. 9:623-629.

Gardner, W.H. 1965. Water content. p. 82-127. In: Methods of Soil Analysis. C.A. Black (Ed.) No. 9 Monogr. Ser. Part I. Amer. Soc. Agron.

Hanks, R.J., and K.L. Anderson. 1957. Pasture burning and moisture conservation. J. Soil and Water Conserv. 12:228-229.

Heyward, F., and R.M. Barnette. 1934. Effect of frequent fires on chemical composition of forests soils in the longleaf pine region. J. Forest. 33:88-90.

Isaac, L.A., and H.G. Hopkins. 1937. The forest soil of the douglas fir region, and changes wrought upon it by logging and slash burning. Ecology 18:264-279.

Kemper, W.D., and W.S. Chepil. 1965. Size distribution of aggregates. p. 499-510. In: Methods of Soil Analysis. C. A. Black (Ed.) No. 9 Monogr. Ser. Part I. Amer. Soc. Agron.

Klute, A. 1965. Laboratory measurement of hydraulic conductivity of saturated soil. p. 210-221. In: Methods of Soil Analysis. C.A. Black (Ed.) No. 9 Monogr. Ser. Part I. Amer. Soc. Agron.

Marshall, R., and C. Averill. 1928. Soil alkalinity on recent burns. Ecology 9:533.

Marshall, T.J., and G.B.Stirk. 1950. The effect of lateral movement of water in soil on infiltration measurements. Australian J. Agr. Res. 1:253-265.

Neuenschwander, L.F. 1976. The effects of fire in a sprayed tobosa-mesquite community on Stamford clay soils. PhD Diss. Texas Tech University. Lubbock.

Neuenschwander, L.F., T.L. Whigham, D.N. Ueckert, and H.A. Wright. 1974. Effect of fire on organic carbon and bacterial growth in the mesquite- tobosa community. p. 15. In: Noxious brush and weed control research highlights. H.A. Wright and R.E. Sosebee (Eds.) Texas Tech University, Vol. 5.

Neuenschwander, L. F., S.H. Sharrow, and H.A. Wright. 1975. Review of tobosagrass (Hilaria mutica). Southwestem Natur. 20:255-263.

Nye, P.H., and D.J. Greenland. 1964. Changes in the soil after clearing tropical forests. Plant and Soils 21:101-112.

Pase, C.P., and A.W. Lindenmuth. 1971. Effects of prescribed fire on vegetation and sediment in oak-mountain mahogany chaparral. J. Forest. 69:800-805.

Richards, L.A., ed. 1954. Diagnosis and improvement of saline and alkali soils. U.S. Salinity Lab., U.S. Dep. Agr. Hbk. 60, 166 p.

Rowe, P.B. 1941. Some factors of the hydrology of the Sierra Nevada foothills. Amer. Geophys. Union Trans. 22:90-100.

Sampson, A.W. 1944. Effect of chaparral burning on soil erosion and on soil moisture relations. Ecology 25:171-191.

Scott, V.H. 1956. Relative infiltration rates of burned and unburned upland soils. Amer. Geophys. Union Trans. 37:67-69.

Sharrow, S.H., and H.A. Wright. 1977a. Effects of fire, ash, and litter on soil nitrate, temperature, moisture and tobosagrass production in the rolling plains. J. Range Manage. 30:266-270.

Sharrow, S.H., and H.A. Wright. 1977b. Proper burning intervals for tobosagrass in West Texas based on nitrogen dynamics. J. Range Manage. 30:343-346.

Smith, D.W. 1970. Concentrations of soil nutrients before and after fire. Can. J. Soil Sci. 50:17-29.

Snedecor, G.W., and W.C. Cochran. 1967. Statistical Methods. Sixth Ed. Iowa State Univ. Press, Ames. 593 p.

Stoner, H.R., T.J. Holder, D.L. McClennon, and K.M. Templeton. 1969. Soil Survey of Mitchell County, Texas. U.S. Soil Conserv. Serv. 47 p.

Tarrant, R.F. 1956. Changes in some physical soil properties after a prescribed burn in young ponderosa pine. J. Forest. 54:439-441.

Veihmeyer, F.F., and C.N. Johnston. 1944. Soil-moisture records from burned and unburned plots in certain grazing areas of California. Amer. Geophy. Union Trans. 25:72-84

Veihmeyer, F.F. 1951. Soil moisture, runoff, erosion. Nat. Wool Grower. 4:21-24.

Vlamis, J., and K.D. Gowans. 1961. Availability of N,P, and S after brush burning. J. Range Mange. 14:38-40.

Vomocil, J.A. 1965. Porosity. p. 289-314. In: Methods of Soil Analysis. C.A. Black (Ed.) No. 9 Monogr. Ser. Part I. Amer. Soc. Agron.

Wright, H.A. 1974. Range burning. J. Range Mange. 27:5-11.

\section{Editor's Note:}

Appreciation is expressed to the following people for reviewing manuscripts during 1978 .

Earl Aldon
Dean Anderson
Tom Bartlett
Dale Bartos
Joe Basile
Joseph Baur
E.R. Beaty
Will Blackburn
Charles Bonham
D.D. Briske
Carlton Britton
John Buckhouse
Don Burzlaff
Bill Dahl
Jim Dodd
Gary Donart
John Doyle
Vincint Du Vall

Bob Fertuson

David Foster

Malcolm Furniss

Jesse Gerard

Gerald Gifford

Marshall Haferkamp

R.M. Hansen

Stephan Hatch

Kris Havstad

George Hewitt

Min Hironaka

V.W. Howard

Lynn James

Rex Kartchner

M.M. Kothmann

Bill Krueger

John Launchbaugh
Bill Laycock

Russ Lorenz

Walter Majak

Henry Mayland

Walt McDonough

Rick Miller

William Moore

Lowell Moser

Darwin Nielsen

Jack Nelson

Clenton Owensby

Jeff Powell

Dee Quenton

Bob Raleigh

Dick Rice

Larry Rittenhouse

Henry Schreiber
Phil Sims

Steve Sharrow

Lamar Smith

Mike Smith

Jim Smolik

Forrest Sneva

Jim Stubbendieck

Jerry Stuth

E.W. Tisdale

Phil Urness

Martin Vavra

Willis Vogel

Tad Weaver

Larry White

A.M. Wilson

Alma Winward

Ben Zamora 